\title{
INTERNATIONAL LAW AND THE PROBlem of Change: A TALE of TWO CONVENTIONS
}

\author{
James Crawford ${ }^{*}$
}

\begin{abstract}
Extensive efforts have been made in the modern period to suppress the possession and use of both chemical and nuclear weapons. However, progress towards the abolition of these two types of weapons presents a rather sharp contrast, as this case study shows. In this article the conventional prohibitions on the possession and use of these weapons are outlined, including the recent Treaty on the Prohibition of Nuclear Weapons of 2017. This Treaty prohibits the possession and use of nuclear weapons but it has not been (and likely will not be) ratified by any of the States that possess nuclear weapons. There is a further, and consequent, contrast between the two kinds of weapons in terms of whether a customary prohibition on the possession and use of chemical and/or nuclear weapons exists; this is also examined. Ultimately, there are lessons to be learned in terms of whether international law can change unless those most concerned, in this case the States that possess chemical or nuclear weapons, want it to change.
\end{abstract}

The Short Twentieth Century ended in problems, for which nobody had, or even claimed to have, solutions. As the citizens of the fin-de-siècle tapped their way through the global fog that surrounded them, into the third millennium, all they knew was that an era of history had ended. They knew very little else. Thus, for the first time in two centuries, the world of the 1990 s entirely lacked any system or structure. $^{1}$

\section{INTRODUCTION}

The problem of peaceful change in international law has been a fixture on the agenda throughout the modern period. The League of Nations Covenant gave functions both to the Council (Article 15) and the Assembly (Article 19); these were subsumed in general terms in relation both to the Security Council and the General Assembly under the United Nations Charter. But the core problem is that,

* Judge, International Court of Justice. Thanks to my associate, Rose Cameron, for her considerable assistance with this article. Views expressed are mine alone.

1 Eric Hobsbawm The Age of Extremes 1914-1991 (Michael Joseph, London, 1991) at 558-559. 
while developments occur and even proliferate, the techniques of change are rudimentary: the giving of consent through treaty-making, and the development of customary international law through practices of claim and counter-claim, acceptance and acquiescence - the processes of giving, withholding and withdrawing of consent. The only constituted substantive values in the international system are those that relate to who gives consent, how and to what effect. The rest is all rights and obligations (many of them defeasible, precarious or terminable) deriving from these processes.

One may contrast the mechanisms for reform commonly found in national legal systems. In wellgoverned states, these are constitutional amendment, legislation based on forms of popular representation, executive action under the law, and the adjustment of rights and rules through adjudication. With the exception of the first, there are simulacra of these at the international level. Constitutional amendment is hardly relevant: the basic constitutional doctrine of the law of nations is the doctrine of state sovereignty, ${ }^{2}$ and while that can be reinforced, modulated or undermined, no state is going to agree to amend it. If the United Nations Charter has been analogised to a form of government and thus, in a sense, to a constitution, the fate of 25 years of discussion of Charter reform reveals little or no progress. Multilateral treaties equate to legislation; concluding them these days takes an enormous effort, but it is as nothing compared with the task of amendment. The best that can usually be done is to conclude a new treaty on the subject of the old and rely upon the open-textured rules in arts 41 and 59 of the Vienna Convention on the Law of Treaties to work out the operative consequences. ${ }^{3}$ Executive action is the normal mode of state action, but whether it takes place under the law depends on the available disciplines at national and (perhaps less often) international level. Adjustment through adjudication depends on the good sense of the adjudicator, but if it is available it is usually interstitial in effect.

When one thinks of alternatives, they seem sub-optimal. To take as an example the Paris Agreement (which remarkably lacks any other title, as if there have been no other Paris agreements), this is essentially a set of procedural arrangements for setting unilaterally-determined targets in the matter of carbon emissions in order (it is hoped) to alleviate climate change. ${ }^{4}$ The extent of commitment is unclear, and deliberately so.

Can it be true that our international arrangements "entirely lack any system or structure"? ${ }^{5}$ Can anything but interstitial change be institutionally impossible in time of peace? Can these two things

2 Compare James Crawford Brownlie's Principles of Public International Law (8th ed, Oxford University Press, Oxford, 2012) at 447 ("the basic constitutional doctrine of the law of nations").

3 Vienna Convention on the Law of Treaties 1155 UNTS 331 (opened for signature 23 May 1969, entered into force 27 January 1980).

4 Paris Agreement under the United Nations Framework Convention on Climate Change 55 ILM 743 (opened for signature 22 April 2016, entered into force 4 November 2016).

5 Hobsbawm, above n 1, at 559. 
be simultaneously true? Perhaps we are condemned to trying to rearrange the furniture while sitting on it.

I have discussed the dilemmas of change in international law in general terms elsewhere. ${ }^{6}$ But to talk in general terms risks avoiding the real issue, which is how, given the principle of consent and its particular manifestation in this field, the persistent objector principle, ${ }^{7}$ international law can change unless those most concerned, especially the most powerful, want it to change.

It is proposed to take here by way of a case study the abolition of weapons of mass destruction, specifically chemical ${ }^{8}$ and nuclear weapons. These share two features which are relevant to our theme. First, the case for complete elimination of these weapons is overwhelming. As to chemical weapons (leaving aside marginal and definitional issues such as riot control agents) no-one now defends their use. As to nuclear weapons, we have got accustomed to living under the shadow of deterrence - but the prospect of their actual use has again been raised in the context of North Korea and possible responses to its acquisition and testing of nuclear devices. The actual use of a nuclear weapon on any group or population would surely trigger a wave of revulsion and would reflect terribly on an international system that allowed it to happen. Secondly, extensive efforts have been made in the modern period to suppress the possession and use of these weapons, whether by states or non-state entities, so there is a full record of the ways in which this has been done or attempted. Yet the results so far are rather different, and the differences are telling.

6 James Crawford Chance, Order, Change: The Course of International Law (Martinus Nijhoff, Leiden, 2014) at chs IV and VIII.

7 Now affirmed by the International Law Commission Third report on identification of customary international law UN Doc A/CN.4/682 (27 March 2015) at 59. See also International Law Commission Fourth report on identification of customary international law UN Doc A/CN.4/695 (8 March 2016) at 10.

8 Convention on the Prohibition of the Development, Production, Stockpiling and Use of Chemical Weapons and on their Destruction 1974 UNTS 45 (opened for signature 3 September 1992, entered into force 29 April 1997) [CWC]. Article II(1) defines chemical weapons widely as meaning "toxic chemicals and their precursors, except where intended for purposes not prohibited under this Convention, as long as the types and quantities are consistent with such purposes" as well as munitions specifically designed to cause death or other harm through the toxic properties of those toxic chemicals and any equipment specifically designed for use directly in connection with the employment of those munitions. This definition, which does not depend on the means of dispersal, is adopted by Stuart Casey-Maslen The War Report: Armed Conflict in 2013 (Oxford University Press, New York, 2014) at 297. 


\section{ATTEMPTS TO OUTLAW CHEMICAL WEAPONS}

Attempts to outlaw chemical weapons have a long history. ${ }^{9}$ The Brussels Declaration of 1874 declared that the use of "poison or poisoned weapons" was "especially forbidden"10 and the Hague Regulations of 1899 and 1907 prohibited their use during hostilities. ${ }^{11}$ The Geneva Protocol of 1925 prohibited the use of "asphyxiating, poisonous or other gases, and of all analogous liquids, materials or devices" and "bacteriological methods of warfare" but did not prohibit their development, production or stockpiling. ${ }^{12}$ The Biological Weapons Convention of $1972^{13}$ prohibited the retention or production of biological agents or toxins and of the means of delivering such agents during armed conflict. ${ }^{14}$ While the Biological Weapons Convention does not prohibit the use or possession of chemical weapons, States Parties to the Convention affirmed "the recognised objective of effective prohibition of chemical weapons" and undertook to "continue negotiations in good faith with a view to reaching early agreement on effective measures for prohibiting the development, production and stockpiling of chemical weapons and for their destruction". ${ }^{15}$ The Convention on the Prohibition of the Development, Production, Stockpiling and Use of Chemical Weapons (CWC) was the result of these efforts.

The text of the CWC was drafted by the Conference on Disarmament and approved by the General Assembly on 30 November $1992 .{ }^{16}$ It entered into force on 29 April 1997 and now has 193 parties, Palestine having acceded to the Convention on 17 May 2018. Among United Nations Member States, Israel has signed but not ratified; Egypt, North Korea and South Sudan have neither signed nor

9 Jefferson identifies expressions of a prohibition on chemical weapons as early as 500BC in ancient Hindu Laws: Catherine Jefferson "Origins of the norm against chemical weapons" (2014) 90 International Affairs 647. Oeter describes the prohibition against poison as "probably the most ancient prohibition of a means of combat in international law": Stefan Oeter "Methods and Means of Combat" in Dieter Fleck (ed) The Handbook of International Humanitarian Law (3rd ed, Oxford University Press, New York, 2013) 115.

10 William H Boothby Weapons and the Law of Armed Conflict (2nd ed, Oxford University Press, Oxford, 2016) at 104.

11 Hague Regulations of 1899, art 23(a) prohibits "poison or poisoned arms". Hague Regulations of 1907, art 23(a) prohibits "poison or poisoned weapons".

12 Protocol for the Prohibition of the Use of Asphyxiating, Poisonous or Other Gases, and of Bacteriological Methods of Warfare (signed 17 June 1925, entered into force 8 February 1928).

13 Convention on the Prohibition of the Development, Production and Stockpiling of Bacteriological (Biological) and Toxin Weapons and on their Destruction 1015 UNTS 163 (opened for signature 10 April 1972, entered into force 26 March 1975).

14 Article I.

15 Article IX.

16 Convention on the Prohibition of the Development, Production, Stockpiling and Use of Chemical Weapons and on Their Destruction GA Res 47/39 (1992) at [1]. 
ratified. The CWC preserves obligations under the Geneva Protocol of 1925 and the Biological Weapons Convention of $1972 .{ }^{17}$

The CWC prohibits the use of chemical weapons under any circumstances, ${ }^{18}$ as well as the development, production, acquisition, stockpiling and retention of chemical weapons and military preparations for their use. ${ }^{19}$ It further prohibits the transfer of chemical weapons and the provision of assistance to anyone to engage in prohibited activity. ${ }^{20}$ It prohibits the use of riot control agents as a method of warfare. ${ }^{21}$

The CWC also contains provisions relating to the non-proliferation of chemical weapons. In particular, States Parties undertake never under any circumstances to assist, encourage or induce anyone to engage in any activity prohibited by the Convention. ${ }^{22}$ Assistance can include material, intellectual or financial support. ${ }^{23}$ Furthermore, States Parties agree to adopt the necessary measures to ensure that toxic chemicals and their precursors are only developed, produced, otherwise acquired, retained, transferred, or used within their territory or in any other place under their jurisdiction or control for purposes not prohibited under the Convention, and to that end they agree to submit to the verification measures set out in Convention. ${ }^{24}$ Along with disarmament, the non-proliferation of chemical weapons is a central feature of the CWC and its obligations apply equally to all Parties. In presenting the draft Convention to the Conference on Disarmament in 1992, the Chairman of the Ad Hoc Committee on Chemical Weapons noted that the total ban on chemical weapons was acceptable to states because the obligations emanating from the Convention "enhanced the security of all and ... were absolutely non-discriminatory". 25

Parties to the CWC must make detailed declarations in relation to their past and present ownership, possession or control of chemical weapons and their chemical weapons production facilities. ${ }^{26}$ Each

17 CWC, above n 8, art XIII.

18 Article I(1)(b). Article I is entitled "General Obligations".

19 Article I(1)(a) and (c).

20 Article I(1)(a) and (d).

21 Article I(5).

22 Article I(1)(d)

23 Walter Krutzch, Eric Myjer and RalfTrapp (eds) The Chemical Weapons Convention: A Commentary (Oxford University Press, Oxford, 2014) at 67.

24 CWC, above n 8, art VI(2).

25 See Report of the Conference on Disarmament UN Doc A/47/27 (1992) at 37-38.

26 CWC, above n 8, art III and Verification Annex, pt IV(A) at [1]-[6]. These declarations must include whether the State Party owns, possesses or controls chemical weapons, the location and quantity of the weapons and the "general plan" for the destruction of the weapons. 
Party undertakes to destroy any chemical weapons it owns, possesses or controls, as well as any chemical weapons it has abandoned on another state's territory, and further undertakes to destroy any chemical weapons production facilities it owns, possesses or controls. ${ }^{27}$

The CWC establishes the Organization for the Prohibition of Chemical Weapons (OPCW) to ensure the implementation of the CWC and to oversee verification. ${ }^{28}$ The verification regime is set out in the Annex on Implementation and Verification, which forms an integral part of the CWC. ${ }^{29}$ As part of the strict regime, States Parties are subject to inspections on their territory for verification of compliance including the validity of the initial declaration, of storage facilities and of chemical weapons destruction facilities. ${ }^{30}$ "Challenge inspections" can be conducted by teams designated by the Director-General of the OPCW at the request of another Party that suspects non-compliance. ${ }^{31}$

The CWC is not subject to reservations and its Annexes are not subject to reservations incompatible with its object and purpose. ${ }^{32}$ A Party wishing to withdraw may do so if it decides that "extraordinary events, related to the subject-matter" of the CWC have jeopardized its "supreme interests": 33 days' notice is required. ${ }^{34}$

\section{ATTEMPTS TO OUTLAW NUCLEAR WEAPONS ${ }^{35}$}

Attempts to outlaw nuclear weapons necessarily have a shorter history than attempts to outlaw chemical weapons because nuclear weapons were not developed until the $1940 \mathrm{~s} .{ }^{36}$ From the $1960 \mathrm{~s}$

27 Article I(2)-(4). The Convention contains time limits for destruction, in relation to the date on which the Convention came into force for a particular State Party: see Verification Annex, pt IV(A) at [17].

28 Article VIII(1)

29 Article XVII provides that the Annexes "form an integral part of this Convention. Any reference to this Convention includes the Annexes."

30 See Verification Annex, pt IV(A) at [37]-[70].

31 The procedure for "challenge inspections" is set out in art IX(8).

32 Article XXII.

33 Article XVI(2).

34 Article XVI(2). Notice must be given to all other States Parties, the Executive Council of the OPCW, the Depositary and the Security Council.

35 Some of this material is taken from James Crawford and Phillipe Sands "Legal Aspects of a Nuclear Weapons Convention" in Canberra Commission on the Elimination of Nuclear Weapons Background Papers (Australian Government Publishing Services, Canberra, 1996) 275, in revised form (1998) 6 AYIL 153, with appropriate updating: the lessons of that paper seem still to hold. See also Legality of the Threat or Use of Nuclear Weapons (Advisory Opinion) [1996] ICJ Rep 226 at 249.

36 The first nuclear weapons were developed by the United States between 1942 and 1945 as part of the Manhattan Project. By way of contrast poisoned weapons - predecessors of chemical weapons - have been used since "ancient times", for example in the form of poisoned arrows: Boothby, above n 10, at 103. 
treaties have prohibited the explosion of nuclear weapons in the atmosphere, in outer space and under water ${ }^{37}$ and have created nuclear weapon-free zones. ${ }^{38}$

The Treaty on the Non-Proliferation of Nuclear Weapons of 1968 (NPT) limited the horizontal proliferation of nuclear weapons by prohibiting nuclear-weapon States from transferring nuclear weapons to any recipient and from assisting any non-nuclear-weapon State in the manufacture of nuclear weapons. ${ }^{39}$ The NPT also prohibited the manufacture of nuclear weapons by non-nuclearweapons States. ${ }^{40}$ The NPT has 191 States Parties. All States Parties undertook to pursue negotiations in good faith on effective measures to achieve nuclear disarmament and on a treaty on "general and complete disarmament". ${ }^{41}$ The NPT defines "a nuclear weapon State" in a limited way as a state "which has manufactured and exploded a nuclear explosive device prior to 1 January, 1967". 42 Those States are China, Russia, the United States, the United Kingdom and France. Four other States India, Pakistan, Israel and North Korea - are known to have or suspected of having nuclear weapons. ${ }^{43}$ This article uses "States that possess nuclear weapons" to denote these nine States.

The Comprehensive Nuclear-Test-Ban Treaty ${ }^{44}$ of 1996 prohibits the carrying out of any nuclear weapons test explosion, but has not yet come into force. ${ }^{45}$ Alongside these multilateral agreements, a

37 Treaty Banning Nuclear Weapon Tests in the Atmosphere, in Outer Space and Under Water 480 UNTS 43 (signed 5 August 1963, entered into force 10 October 1963), art 1(a).

38 There are five nuclear weapons-free zones: in Latin America (Treaty for the Prohibition of Nuclear Weapons in Latin America 634 UNTS 326 (opened for signature 14 February 1967, entered into force 25 April 1969)); the South Pacific (South Pacific Nuclear Free Zone Treaty 1445 UNTS 177 (opened for signature 6 August 1985, entered into force 11 December 1986)); Southeast Asia (Southeast Asia Nuclear Weapon-Free Zone 1981 UNTS 129 (opened for signature 15 December 1995, entered into force 28 March 1997)); Africa (African Nuclear Free Zone Treaty 35 ILM 698 (opened for signature 11 April 1996, entered into force 15 July 2009) [Treaty of Pelindaba]); and Central Asia (Treaty on a Nuclear-Weapon-Free-Zone in Central Asia (opened for signature 8 September 2006, entered into force 21 March 2009)). Nuclear explosions are prohibited in the Antarctic pursuant to art V of The Antarctic Treaty 402 UNTS 71 (signed 1 December 1959, entered into force 23 June 1961). Article VII of the NPT preserved the right of any group of states to conclude regional treaties to "assure the total absence of nuclear weapons in their respective territories".

39 Treaty on the Non-Proliferation of Nuclear Weapons 729 UNTS 161 (opened for signature 1 July 1968, entered into force 5 March 1970) [NPT], art 1.

40 Article II.

41 Article VI.

42 Article IX(3)

43 Shannon N Kile and Hans M Kristensen Trends in World Nuclear Forces (Stockholm International Peace Research Institute, 2017) at 1.

44 Comprehensive Nuclear-Test-Ban Treaty 35 ILM 1439 (opened for signature 10 September 1996, not yet in force).

45 Article I of the Comprehensive Nuclear-Test-Ban Treaty prohibits any nuclear weapons test explosion. The Convention will not come into force until all of the States listed in its Annex 2 have ratified it (art XIV). 
series of bilateral negotiations have taken place between the United States and the Soviet Union, and from 1991, between the United States and Russia. ${ }^{46}$ However, until 2017 there was no treaty prohibition on the possession and use of nuclear weapons in every circumstance.

The text of the Treaty on the Prohibition of Nuclear Weapons (TPNW) was adopted on 7 July 2017 at the United Nations Conference to Negotiate a Legally Binding Instrument to Prohibit Nuclear Weapons, Leading Towards their Total Elimination. ${ }^{47}$ The General Assembly had convened the conference on the recommendation of an Open-ended Working Group tasked with addressing "concrete effective legal measures, legal provisions and norms that will need to be concluded to attain and maintain a world without nuclear weapons". ${ }^{48}$ One hundred and twenty-two countries voted in favour of the Treaty text, the Netherlands voted against it and Singapore abstained. None of the States that possess nuclear weapons participated in the Conference or the vote. ${ }^{49}$ The Treaty opened for signature on 20 September 2017 and was signed by 50 States on that date. ${ }^{50}$ It is not yet in force but will commence 90 days after 50 States have ratified it. ${ }^{51}$ The Treaty preserves obligations undertaken

Annex 2 States are those that formally participated in the 1996 Conference on Disarmament and possessed nuclear reactors at that time. China, Egypt, the United States, Israel, Iran, India, North Korea and Pakistan are the Annex 2 States which have not yet ratified the Treaty.

46 Two sets of Strategic Arms Limitation Talks (SALT I and II) took place between 1969 and 1979 and resulted in agreements in which the two parties agreed to limit their arsenals of particular weapons, including intercontinental ballistic missiles (ICBMs) and submarine-launched ballistic missiles (SLBMs). These negotiations were followed by five further rounds of negotiating dubbed START (Strategic Arms Reduction Treaty) I, II and III; SORT (Strategic Offensive Reductions Treaty); and the New START, which also involved attempts to agree on limitations of both States' arsenal of ICBM and SLBM warheads, amongst other weapons. Strategic Arms Reduction Treaty (entered into force 5 December 1994) [START I]; the Strategic Arms Reduction Treaty (3 January 1993, did not enter into force) [ST ART II]; Strategic Offensive Reductions Treaty (24 May 2002, entered into force 1 June 2003) [SORT]; and Treaty between the United States of America and the Russian Federation on Measures for Further Reduction and Limitation of Strategic Offensive Arms 111-5 TIAS (signed 8 April 2010, entered into force 5 February 2011) [New START].

47 Treaty on the Prohibition of Nuclear Weapons 729 UNTS 161 (opened for signature 20 September 2017, not yet in force) [TPNW].

48 The Open-ended Working Group was given its mandate pursuant to Taking forward multilateral nuclear disarmament negotiations GA Res 70/33 (2015) at [2]. See also in relation to the steps that preceded the adoption of the Treaty text United Nations Office for Disarmament Affairs "TPNW" (24 July 2017) $<$ www.un.org $>$.

49 See UN "United Nations Conference to Negotiate a Legally Binding Instrument to Prohibit Nuclear Weapons, Leading Towards their Total Elimination" $<$ www.un.org $>$.

50 United Nations Office for Disarmament Affairs "List of Countries which Signed Treaty on the Prohibition of Nuclear Weapons on Opening Day" (20 September 2017) <www.un.org>.

51 TPNW, above $\mathrm{n} 47$, art 15 . So far 19 States have ratified the TPNW. 
with regard to existing international agreements where those obligations are consistent with the Treaty. ${ }^{52}$

The TPNW prohibits the use or threat of use of nuclear weapons under any circumstances. ${ }^{53}$ It also prohibits under any circumstances the development, testing, production, manufacture, acquiring, possessing or stockpiling of nuclear weapons ${ }^{54}$ Finally it prohibits the transfer and receipt of nuclear weapons, the provision of assistance to anyone to engage in activity prohibited by it, and the installation of nuclear weapons on any territory under a Party's control. ${ }^{55}$ It safeguards States Parties' "inalienable right" to develop nuclear energy for peaceful purposes, although only by way of a preambular paragraph. ${ }^{56}$

Each Party must make a detailed declaration within 30 days of the TPNW's entry into force for that state in relation to its past and current ownership, possession or control of nuclear weapons. ${ }^{57}$ The TPNW provides for a verification regime but only in broad terms. Parties must designate a "competent international authority" to "negotiate and verify the irreversible elimination of nuclearweapons programmes". ${ }^{58}$ In the event the competent authority is not designated prior to the TPNW's entry into force for a State that owns, possesses or controls nuclear weapons or other nuclear explosive devices (or did so at any time after 7 July 2017), the United Nations Secretary-General will convene an extraordinary meeting at which the decision will be made. ${ }^{59}$ Any Party that owns, possesses or controls nuclear weapons after 7 July 2017 must destroy them and coordinate the "irreversible elimination of its nuclear-weapons programme" with the competent international authority. ${ }^{60}$ All Parties, whether or not they possess nuclear weapons, must comply with their existing International Atomic Energy Agency (IAEA) safeguard obligations or conclude a comprehensive safeguards agreement with the IAEA if they do not already have one. ${ }^{61}$

52 Article 18.

53 Article 1(d).

54 Article 1(a).

55 Article 1(b)-(c) and (e)-(g).

56 The NPT contains the same safeguard in its art IV. Article IV of the NPT also mandates cooperation between its States Parties in the development of nuclear energy for peaceful purposes.

57 TPNW, above $\mathrm{n} 47$, art 2.

58 Article 4(6)

59 Article 4(6).

60 Article 4(1)-(2).

61 See art 3(1) in relation to compliance with existing IAEA safeguards obligations by States with no nuclear weapons; art 3(2) in relation to new safeguards agreements between the IAEA and States with no nuclear weapons; and art 4 in relation to States which possess nuclear weapons after 7 July 2017. 
The TPNW is not subject to reservations. ${ }^{62}$ Parties wishing to withdraw may do so if they decide that "extraordinary events related to the subject matter of the Treaty have jeopardized" their "supreme interests". ${ }^{63}$ However withdrawal will only take effect 12 months after receipt of a notification of withdrawal. Furthermore, if that state is, on the expiry of that 12 month period, a party to an armed conflict the state remains bound by the Treaty until it ceases to be a party to an armed conflict. ${ }^{64}$ In theory this prevents withdrawal even in case of jeopardy of "supreme interests" if this is for the purpose of using nuclear weapons in an existing armed conflict.

\section{CONTRASTS BETWEEN THE TWO FIELDS}

\section{A Support for an International Prohibition}

The development of an international agreement prohibiting chemical weapons had the support of the United States and the Soviet Union from the late 1960s. At that time both possessed chemical weapons ${ }^{65}$ and at the time of their accession to the CWC in 1997, both declared that they continued to possess chemical weapons. ${ }^{66}$ Bilateral efforts between the United States and the Soviet Union to reach an agreement prohibiting chemical weapons progressed alongside multilateral efforts. Multilateral negotiations intensified after 1968, when chemical weapons disarmament became an active issue for consideration by the Geneva disarmament conference.

The efforts of the United States and the Soviet Union led to a number of agreements which facilitated the establishment of the $\mathrm{CWC}^{67}$ and culminated in an important agreement in 1990

62 Article 16.

63 Article 17(1). Parties to the NPT can withdraw from that Treaty on an identical basis: see NPT, above n 39 , art $\mathrm{X}(1)$.

64 TPNW, above n 47, art 17(1).

65 See JP Robinson "The Negotiations on the Chemical Weapons Convention: A Historical Overview" in Michael Bothe, Natalino Ronzitti and Allan Rosas (eds) The New Chemical Weapons Convention Implementation and Prospects (Kluwer Law International, The Hague, 1998) 22; and US-USSR Joint Communiqué at the end of US official visit to the USSR in May 1972 (30 May 1972): "The USA and USSR will continue their efforts to reach an international agreement regarding chemical weapons."

66 As at 20 November 1998, three States Parties had made declarations of current holdings of chemical weapons: India, the United States and an unnamed "one other": OPCW Report of the Organisation on the Implementation of the Convention (C-III/3, 20 November 1998) at [5.20]. As at 2 July 1999, Russia had also made a declaration of current holdings of chemical weapons: OPCW Report of the Organisation on the Implementation of the Convention (C-IV/5, 2 July 1999) at [4]. Other Parties that have declared the possession of chemical weapons (whether functional or abandoned) include Albania, India, Libya, Russia, Syria, China and Japan: Report of the OPCW on the Implementation of the Convention on the Prohibition of the Development, Production, Stockpiling and Use of Chemical Weapons and on their Destruction in 2015 (C21/4, 30 November 2016) at [1.2]. Iraq, Libya, Russia, Syria and the United States still have declared chemical weapons: at [1.7].

67 OPCW "History: Looking back helps us look forward" <www.opcw.org > 
following negotiations in Washington. In that 1990 agreement the United States and the Soviet Union set out their determination to: 68

... make every effort to conclude and to bring into force at the earliest date a convention providing for a

global ban on the development, production, stockpiling and use of chemical weapons and on their

destruction.

They also agreed to destroy the bulk of their chemical weapon stockpiles by the end of 1992. Also in 1992, the General Assembly resolution commending the CWC for signature was adopted without a vote, demonstrating the consensus reached in relation to the Convention text. ${ }^{69}$ Within two days of the CWC opening for signature in January 1993, 130 States had become signatories. ${ }^{70}$ By the end of 1997 (the year the CWC came into force) there were 105 States Parties to the $\mathrm{CWC}^{71}$ and there has now been near-universal accession. ${ }^{72}$

By way of contrast the 2017 prohibition of the possession and use of nuclear weapons in all circumstances did not receive the support of any State that possesses nuclear weapons. The United States, France and the United Kingdom announced that they do not intend to ever become a party to the TPNW. ${ }^{73}$ Russia, which did not attend the vote on the TPNW in the General Assembly, has stated that the Treaty will not change the "reality in the field of strategic stability that mandates us to exercise utmost caution and responsibility with our evaluations of the future of nuclear disarmament". ${ }^{74}$ All of the States that possess nuclear weapons, and all of their strategic military allies, either failed to attend

68 Agreement on Destruction and Non-production of Chemical Weapons and on Measures to Facilitate the Multilateral Convention on Banning Chemical Weapons, Union of Soviet Socialist Republics-United States (1 June 1990).

69 GA Res 47/39, above n 16

70 OPCW Technical Secretariat Background paper on universal adherence to the Chemical Weapons Convention (RC-1/S/5, 25 April 2003) at [7].

71 OPCW Report of the Organisation on the Implementation of the Convention, above $\mathrm{n} 66$, at [4.1].

72 Israel has signed but not ratified the Convention. Egypt, North Korea and South Sudan have neither signed nor ratified it. Palestine has also not ratified the CWC. See International Committee of the Red Cross "Conference of the States Parties to the Chemical Weapons Convention: statement by the ICRC, 2016" (30 November 2016).

73 "Joint Press Statement from the Permanent Representatives to the United Nations of the United States, United Kingdom, and France Following the Adoption of a Treaty Banning Nuclear Weapons" (7 July 2017) [France, United Kingdom and United States Joint Press Statement].

74 Permanent Mission of the Russian Federation to the United Nations "Russian Mission's comments on the Treaty for the Prohibition of Nuclear Weapons" (27 September 2017). 
the vote on the TPNW or voted against the Treaty. Of the 29 North Atlantic Treaty Organization Member States, 28 did not attend; the Netherlands attended but voted against. ${ }^{75}$

\section{$B$ Condemnation of Use and Possession}

No state defends the use or possession of chemical weapons, including for deterrent purposes. ${ }^{76}$ The 193 Parties to the CWC have undertaken not to use or possess chemical weapons in any circumstance and States Parties have further committed to a fixed timeline towards the destruction of any chemical weapons under their control. ${ }^{77}$ Three of the four States that have not ratified the Convention have condemned the use and possession of chemical weapons through other means: Egypt, Israel and North Korea are parties to the Geneva Protocol on Poisonous Gases and have also officially denied production and possession of chemical weapons. ${ }^{78}$ In addition, Egypt supported the Security Council's recent attempt to pass a resolution condemning a perceived failure on behalf of Syria to cooperate with OPCW inspectors. ${ }^{79}$ While the quasi-universal accession to the CWC was achieved over 20 years ${ }^{80}$ some States that have recently acceded had previously condemned the use and possession of chemical weapons. ${ }^{81}$ Moreover the OPCW has identified "administrative or bureaucratic" reasons, other than disagreement with the obligations enshrined in the CWC, why some States took years to ratify the CWC. ${ }^{82}$

75 "United Nations conference to negotiate a legally-binding instrument to prohibit nuclear weapons: Second session" (record of voting, 7 July 2017).

76 See Jean-Marie Henckaerts and Louise Doswald-Beck Handbook on International Customary Humanitarian Law (International Committee of the Red Cross, 2009) at 263.

77 CWC, above n 8, Annex on Implementation and Verification, pt IV(A) at [17].

78 In relation to Israel, see International Committee of the Red Cross (ICRC) Customary International Humanitarian Law (Cambridge University Press, Cambridge, 2005) at 261 and 1697. The ICRC has identified relevant statements by Israel in 1987, 1991, 1995 and 1997. At the 17th session of the OPCW in 2012 Israel stated that "it attaches great importance to the CWC and supports its goals". In relation to Egypt, see at 16891690. The ICRC has identified relevant statements from 1988 and 1990. In relation to North Korea, see at 261 and 1700. The ICRC noted relevant statements in 1989 and 1995. However the Midterm report of the Panel of Experts established pursuant to resolution 1874 (2009) (5 September 2017) at [28], did note that North Korea is suspected of shipping prohibited chemical weapons to Syria.

79 Security Council 7922nd meeting (PM) UN Doc S/PV.7922 (12 April 2017).

80 On 31 July 1997 there were 95 Parties; three States had acceded to the CWC but it not yet entered into force for them and a further 69 had signed but not ratified the Convention: OPCW Technical Secretariat Status of the Convention on the Prohibition of the Development, Production, Stockpiling and Use of Chemical Weapons and on their Destruction (S/6/97, 4 August 1997).

81 For example, Myanmar acceded to the CWC in 2015. It explained the late accession by reference to "domestic circumstances". See U Wunna Maung Lwin, Union Minister for Foreign Affairs "Myanmar: Statement at the 79th session of the Executive Council of the OPCW" (9 July 2015) at [10].

82 In 2003 the OPCW said that the 45 States that remained non-parties had "administrative or bureaucratic" reasons, such as a lack of financial and human resources to undertake the parliamentary or other legislative 
Several States continue to defend the legality of the possession of nuclear weapons, especially through the maintenance of policies of nuclear deterrence. ${ }^{83}$ The United Kingdom, the United States and France demonstrated their adherence to a policy of nuclear deterrence in their response to the TPNW by stating that: ${ }^{84}$

Accession to the ban treaty is incompatible with the policy of nuclear deterrence, which has been essential

to keeping the peace in Europe and North Asia for over 70 years.

The Parties to the NPT, which by 1992 included all the nuclear-weapon States as defined by that Treaty, ${ }^{85}$ undertook to pursue negotiations in good faith towards nuclear disarmament and a treaty on "general and complete disarmament". ${ }^{86}$ However, States Parties to the NPT made no specific commitment in terms of a timeline for disarmament. All of the nuclear-weapon States (again as defined in the NPT) except China, ${ }^{87}$ maintain their right to first use of nuclear weapons. ${ }^{88}$ The United

actions necessary to adopt and implement the Convention. The OPCW also noted "other pressing issues of critical importance" for these States to attend to, such as AIDS, desertification, conflict and poverty: OPCW Technical Secretariat, above n 70, at [22].

83 See United States Department of Defense Nuclear Posture Review (February 2018) at VI: "US nuclear capabilities make essential contributions to the deterrence of nuclear and non-nuclear aggression. The deterrence effects they provide are unique and essential to preventing adversary nuclear attacks, which is the highest priority of the United States." See also North Atlantic Treaty Organization "North Atlantic Council Statement on the Treaty on the Prohibition of Nuclear Weapons" (20 September 2017): "The fundamental purpose of NATO's nuclear capability is to preserve peace, prevent coercion, and deter aggression. Allies' goal is to bolster deterrence as a core element of our collective defence and to contribute to the indivisible security of the Alliance. As long as nuclear weapons exist, NATO will remain a nuclear alliance." See United Kingdom Ministry of Defence "The UK's nuclear deterrent: what you need to know" (policy paper, 19 February 2018) <www.gov.uk>: "since 1969, the Royal Navy has delivered the nuclear deterrent under Operation Relentless ... our retention of an independent centre of nuclear decision making makes clear to any adversary that the costs of an attack on UK vital interests will outweigh any benefits".

84 France, United Kingdom and United States Joint Press Statement, above n 73.

85 NPT, above n 39, art IX(3): for the purposes of the NPT "a nuclear-weapon State is one which has manufactured and exploded a nuclear weapon or other nuclear explosive device prior to 1 January 1967", namely China, the United States, the Soviet Union, the United Kingdom and France.

86 Article VI.

87 China claims that it has maintained its no-first-use policy ever since 1964 "on the day China conducted its first nuclear test": Implementation of the Treaty on the Non-Proliferation of Nuclear Weapons in the People's Republic of China: Report submitted by China UN Doc NPT/CONF.2015/32 (27 April 2015) at [7]. See also Xinhua "China reiterates non-first-use principle of nuclear weapons" (18 February 2018) $<$ www.xinhuanet.com>.

88 The United Kingdom's stance is unclear; however first use of a nuclear weapon is not ruled out in its definition of "modern deterrence": United Kingdom Cabinet Office National Security Capability Review (March 2018) at 11. See also Rob Merrick "Theresa May would fire UK's nuclear weapons as a 'first strike', says Defence Secretary Michael Fallon" The Independent (online ed, United Kingdom, 24 April 2017). France's stance is also unclear and does not rule out the first use of nuclear weapons: see French Senate La nécessaire 
States maintains this policy expressly: in its 2018 Nuclear Posture Review it explained that it "has never adopted a 'no first use' policy and, given the contemporary threat environment, such a policy is not justified today". ${ }^{89}$ The United States further articulated its declaratory policy regarding the potential employment of nuclear weapons to include that it "would only consider the employment of nuclear weapons in extreme circumstances [and these] could include significant non-nuclear strategic attacks". ${ }^{90}$ Similarly Russia's 2014 military doctrine reserves: $:{ }^{91}$

... the right to use nuclear weapons ... in the event of aggression against the Russian Federation with the use of conventional weapons when the very existence of the state is in jeopardy.

In responding to the United States' 2018 Nuclear Posture Review, Russia stated that its military doctrine limited the use of nuclear weapons more strictly than that of the United States, which did not limit their use to specific "military scenarios". 92

\section{Belligerent Reprisals}

Very few states maintain the right to use chemical weapons by way of belligerent reprisals and none appear to advocate this openly. All Parties to the CWC have now undertaken not to use chemical weapons in any circumstance. Of the four States that are not parties to the Convention, three (Egypt, Israel and North Korea) are parties to the Geneva Protocol on Poisonous Gases and therefore have undertaken never to use asphyxiating or poisonous gases, or bacteriological methods of warfare. ${ }^{93}$ However Israel and North Korea remain outliers given their implicit maintenance of a right of belligerent reprisal involving the use of chemical weapons. This purported right of belligerent reprisal is evidenced by their reservations to the Geneva Protocol. These reservations are to the effect that they reserve the right to retaliate with chemical weapons should another state use them first.

modernisation de la dissuasion nucléaire (28 June 2017); French Senate La dissuasion nucléaire: quel rôle pour la défense française aujourd'hui? (24 October 2006); and Pierre Alonso "Dissuasion nucléaire: la France bille en têtes" Libération (online ed, France, 7 February 2018). All nuclear weapon States, except China, abstained from Conclusion of effective international arrangements to assure non-nuclear-weapon States against the use or threat of use of nuclear weapons GA Res 70/25 (2015), which reaffirmed "the urgent need to reach an early agreement on effective international arrangements to assure non-nuclear-weapon States against the use or threat of use of nuclear weapons".

89 United States Department of Defense, above n 83, at 22.

90 At 21.

91 President of the Russian Federation "The Military Doctrine of the Russian Federation" (press release, 25 December 2014) at [27], available in English on the website of the Russian Embassy to the United Kingdom of Great Britain and Northern Ireland <https://rusemb.org.uk>.

92 The Ministry of Foreign Affairs of the Russian Federation "Comment by the Information and Press Department on the new US Nuclear Posture Review" (3 February 2018) <www.mid.ru/en>.

93 Protocol for the Prohibition of the Use of Asphyxiating, Poisonous or Other Gases, and of Bacteriological Methods of Warfare, above n 12. 
Some States that possess nuclear weapons expressly maintain their right to use nuclear weapons by way of belligerent reprisals. An example is provided by reservations entered in relation to Protocol I of the African Nuclear Weapon Free Zone Treaty (Treaty of Pelindaba). ${ }^{94}$ States Parties to the Treaty undertake not to conduct research on, develop, manufacture, stockpile or otherwise acquire, possess or have control over any nuclear explosive device by any means anywhere. ${ }^{95}$ Parties to the Protocol undertake not to use or threaten to use nuclear weapons against any Party to the Treaty. ${ }^{96}$ China, France, Russia, the United Kingdom and the United States have signed Protocol I but the United States has not ratified it. Upon ratification in 2001, the United Kingdom made the following Declaration, among others:

... the Government of the United Kingdom will not be bound by their undertaking under Article I of

Protocol I;

(i) in the case of an invasion or any other attack on the United Kingdom, its dependent territories, its armed

forces or other troops, its allies or a State towards which it has a security commitment, carried out or

sustained by a Party to the Treaty in association or alliance with a nuclear-weapon State ...

Thus the United Kingdom reserves the right to retaliate with the use of nuclear weapons against an attack by a State which is associated or allied with a nuclear-weapon State.

In its Advisory Opinion on Legality of the Threat or Use of Nuclear Weapons, the International Court of Justice expressly declined to decide whether the use of nuclear weapons in the conduct of belligerent reprisals could ever be lawful. ${ }^{97}$ However the Court did survey other international instruments in which States possessing nuclear weapons had undertaken not to use nuclear weapons against non-nuclear-weapon States but reserved their right to respond in kind to aggression supported by a nuclear-weapon State. ${ }^{98}$ The Court did observe that armed reprisals in time of peace are "considered to be unlawful"99 and that any right of recourse to belligerent reprisals would be governed by the principle of proportionality. ${ }^{100}$ In this regard belligerent reprisals, whether by the use of chemical or nuclear weapons, or conventional weapons, would be unlawful unless they were

94 Treaty of Pelindaba, above n 38.

95 Article 3(a).

96 Protocol I art 1.

97 Legality of the Threat or Use of Nuclear Weapons, above n 35, at 246.

98 At 246. The Court referred to Protocols and accompanying reservations to the Treaty for the Prohibition of Nuclear Weapons in Latin America, above n 38, and the South Pacific Nuclear Free Zone Treaty, above n 38. Since the Advisory Opinion, the Treaty of Pelindaba, above n 38, and the Treaty on a Nuclear-Weapon-FreeZone in Central Asia, above n 38, have come into force; they include a similar Protocol.

99 Legality of the Threat or Use of Nuclear Weapons, above n 35, at 246.

100 At 246. 
proportionate and consistent with the requirements of the United Nations Charter, in particular Article $51 .{ }^{101}$

\section{Development of Weapons}

The conventional prohibition on the development of chemical weapons has been in force since 1997 and now applies to 193 States. The conventional prohibition on the development of nuclear weapons is not yet in force, but the TPNW has 69 signatory States and 19 States Parties. ${ }^{102}$

No state is openly developing new chemical weapons. The OPCW has destroyed 90 per cent of the world's declared stockpile of chemical agents and 57.32 per cent of its chemical munitions. ${ }^{103}$ The OPCW's annual reports suggest that parties which have declared chemical weapons are generally cooperating with the Organization in the destruction of these weapons and are allowing inspections on their territory pursuant to the obligations under the CWC. ${ }^{104}$ However, the OPCW has reported the probable use of chemical weapons in Syria in $2017^{105}$ and in the United Kingdom in 2018. ${ }^{106}$

101 Crawford, above n 2, at 564-565; and Matthias Ruffert "Reprisals" in Max Planck Encyclopaedia of International Law (September 2015) at [10].

102 As at 3 October 2018.

10369,059 metric tonnes, or 90 per cent, of the world's declared stockpile of 72,304 metric tonnes of chemical agent and 4.97 million, or 57.32 per cent, of the 8.67 million chemical munitions and containers covered by the CWC have been verifiably destroyed as at 1 July 2017: OPCW "OPCW by the numbers" (1 July 2017) <www.opcw.org>.

104 Report of the OPCW on the Implementation of the Convention on the Prohibition of the Development, Production, Stockpiling and Use of Chemical Weapons and on their Destruction in 2015, above n 66. In relation to destruction of chemical weapons, see [4] and [1.4]-[1.21]. In relation to inspections see [5] and [1.1].

105 The OPCW's fact-finding mission in Syria concluded that sarin was "very likely used as a chemical weapon in the south of Ltamenah on 24 March 2017": OPCW Technical Secretariat Report of the OPCW Fact-Finding Mission in Syria Regarding Alleged Incidents in Ltamenah, the Syrian Arab Republic on 24 and 25 March 2017 (S/1636/2018, 13 June 2018) at [1.8] and that "chlorine was very likely used as a chemical weapon at Ltamenah Hospital and the surrounding area on 25 March 2017" at [1.10]. OPCW Progress in the Elimination of the Syrian Chemical Weapons Programme (EC-89/DG.24, 24 September 2018) at [6] stated that progress in the elimination of the Syrian chemical weapons programme reported the destruction of 27 chemical weapons production facilities.

106 OPCW Technical Secretariat Summary of the Report on Activities Carried out in Support of a Request for Technical Assistance by the United Kingdom of Great Britain and Northern Ireland (S/1671/2018, 4 September 2018). 
By comparison States that possess nuclear weapons are maintaining and upgrading their arsenals. ${ }^{107}$ While there has only been limited horizontal nuclear proliferation since $1945,{ }^{108}$ the vertical proliferation of nuclear technologies within States that possess nuclear weapons has not ended.

\section{E Multilateral or Bilateral Agreements}

The comprehensive prohibition on the use and possession of chemical weapons has been incorporated in a multilateral convention, the CWC. However, the support of the United States and Russia (and before that, the Soviet Union) for various initiatives linked to the development of the conventional prohibition was crucial. ${ }^{109}$ Such initiatives included United States-Soviet agreement in relation to on-site inspections and precursor control, as well as a willingness by the early 1990s to commit to a reduction in their own chemical weapons arsenals. ${ }^{110}$ At the same time the United States was able to demonstrate a commitment to the non-use of chemical weapons in armed conflict by avoiding their use during the Gulf War. By 1990, in the context of that armed conflict, the United States appeared to be acting pursuant to a perceived political and moral imperative against the use of chemical weapons. ${ }^{111}$

To date, the most concrete nuclear disarmament agreements have been achieved bilaterally rather than through multilateral agreement. This is because the United States and Russia possess the

107 Preparatory Committee for the 2015 Review Conference of the Parties to the Treaty on the Non-Proliferation of Nuclear Weapons Article VI of the Treaty on the Non-Proliferation of Nuclear Weapons: Working Paper submitted by Ireland on behalf of the New Agenda Coalition UN Doc NPT/CONF.2015/PC.III/WP.18 (2 April 2014) at [7]. The United Kingdom estimates that the manufacturing of the four Dreadnought submarines which will replace its current Vanguard submarines as part of its nuclear deterrence policy will cost $£ 31$ billion with a contingency of $£ 10$ billion. They are to be introduced "from the 2030s". See United Kingdom Ministry of Defence "Dreadnought submarine programme: factsheet" (policy paper, 19 February 2018) $<$ www.gov.uk>. In relation to the United States, see Congressional Budget Office Projected Costs of US Nuclear Forces, 2017 to 2026 (February 2017) at 4, which includes costing for "[s]ome modernization plans, particularly for a new bomber ... ICBM [Intercontinental Ballistic Missile] modernization and the new cruise missile."

108 Certain States, including South Africa, Brazil, Argentina and Sweden, considered or commenced the development of nuclear weapons programmes but have officially ceased these, according to the Report of the Canberra Commission on the Elimination of Nuclear Weapons (Australian Government Publishing Services, August 1996) at 29. South Africa, Brazil, Argentina and Sweden voted in favour of the Treaty on the Prohibition of Nuclear Weapons.

109 Robinson, above n 65, at 25.

110 At 25; and Agreement on Destruction and Non-production of Chemical Weapons and on Measures to Facilitate the Multilateral Convention on Banning Chemical Weapons, above n 68.

111 Richard M Price The Chemical Weapons Taboo (Ithaca, Cornell University Press, 1997) at 149-150. 
overwhelming majority of nuclear weapons in the world. ${ }^{12}$ While the NPT included general obligations on nuclear-weapon States to pursue negotiations in good faith on effective measures relating to nuclear disarmament, ${ }^{113}$ bilateral agreements between the United States and Russia have included concrete undertakings to abide by timelines for nuclear disarmament. For example, pursuant to the New START, ${ }^{114}$ which entered into force in February 2011, the United States and Russia must meet maximum arsenal targets by February 2018. The targets are specific. ${ }^{115}$ However in response to Russia's perceived uncertainty as to the United States' commitment to the New START ${ }^{116}$ as well as concern over horizontal nuclear proliferation, Russia has suggested that nuclear disarmament agreements take place in future in a multilateral setting. In a statement in response to the TPNW in September 2017, the Russian Mission to the United Nations said: 117

Russia cannot move any further in the reduction of its nuclear weapons based only on bilateral agreements with the US (not to mention that the position of the Administration of President D. Trump on the New START or the INF [Intermediate-Range Nuclear Forces] Treaty remains uncertain). We have de facto reached the line after which relevant hypothetical negotiations should be held in a multilateral setting. We cannot continue to ignore the potential of all other nuclear weapon states any longer.

This statement is at odds with its previous stance on the issue. Indeed Russia (as well as every other nuclear-weapon State, as defined in the NPT) voted against the General Assembly's 2015 resolution which established the Open-Ended Working Group tasked with progressing multilateral nuclear disarmament negotiations. ${ }^{118}$ Russia (as well as the United States, the United Kingdom and France) also voted against a resolution during the same General Assembly session which reaffirmed "the continued importance and relevance of multilateral disarmament machinery as mandated by the

112 The Federation of American Scientists estimated the global possession of nuclear warheads in 2017 as follows: Russia, 7,000; the United States, 6,800; France, 300; China, 270; the United Kingdom, 215; Pakistan, 120-130; India, 110-120; Israel, 80; North Korea, less than 10: cited in International Campaign to Abolish Nuclear Weapons "Nuclear arsenals" <www.icanw.org>.

113 NPT, above n 39, art VI.

114 New START, above n 46.

115 For example, a limit of 1,550 nuclear warheads on deployed ICBMs, deployed submarine-launched ballistic missiles and deployed heavy bombers equipped for nuclear armaments (each such heavy bomber is counted as one warhead toward this limit): United States Department of State "New START" <www.state.gov>.

116 According to United States State Department, Department Spokesperson Heather Nauert "Conclusion of UN Negotiations on a Treaty to Ban Nuclear Weapons" (press release, 7 July 2017), the United States "remain[s] on track to meet the central limits of the New START Treaty when they take effect in February 2018, which will cap US and Russian nuclear forces at their lowest levels since the 1950s".

117 Permanent Mission of the Russian Federation to the United Nations, above $\mathrm{n} 74$.

118 GA Res 70/33, above n 48, emphasised "the importance of addressing issues related to nuclear weapons in a comprehensive, inclusive, interactive and constructive manner, for the advancement of multilateral nuclear disarmament negotiations". 
General Assembly at its first special session devoted to disarmament" and endorsed "the wide support expressed at the high-level meeting for a comprehensive convention on nuclear weapons". ${ }^{119}$

\section{F Whether the Prohibition on Use is a Customary Prohibition}

There is support for the view that the prohibition on the use in any circumstance of chemical weapons is part of customary international law. ${ }^{120}$ It is generally agreed that the Hague Regulations of 1907 (including the prohibition on poisoned weapons) embody rules of customary international law. ${ }^{121}$ Proponents of a customary prohibition on the use and possession of chemical weapons rely on the uniformity of state practice with regards to the condemnation of the use of chemical weapons: apart from the near-universal ratification of the $\mathrm{CWC}$, there is the long history of attempts to prohibit chemical weapons in treaty form, and the regularity with which states and international organisations refer to an international norm against chemical weapons. There appears to be growing support for a customary prohibition of reprisals using chemical weapons and, almost as a corollary, a customary prohibition on their possession.

One important reason for the success of the CWC is because the prohibition on chemical weapons had a long history which predated that Convention and enabled the customary prohibition on chemical weapons to emerge. The "genealogy of the ban"122 on chemical weapons stretches back through centuries as a ban on poison in warfare but had a more recent embodiment in the form of the 1899 Hague Declaration concerning Asphyxiating Gases. ${ }^{123}$ This history, and The Hague Declaration, provided the "political space" for the eventual total ban on chemical weapons incorporated in the CWC. ${ }^{124}$

119 Follow-up to the 2013 high-level meeting of the General Assembly on nuclear disarmament GA Res 69/58 (2014).

120 See for example Henckaerts and Doswald-Beck, above n 76, at rule 74; the United Kingdom's statement that the prohibition on the use of chemical weapons is customary in "Chemical weapon use by Syrian regime: UK government legal position" (policy paper, 29 August 2013) <www.gov.uk> at [2]; and Report of the United Nations Mission to Investigate Allegations of the Use of Chemical Weapons in the Syrian Arab Republic on the alleged use of chemical weapons in the Ghouta area of Damascus on 21 August 2013: Note by the Secretary-General UN Doc A/67/997 (16 September 2013) at [4].

121 According to the Nuremberg International Military Tribunal Trial of the Major War Criminals, 14 November 1945-1 October 1946 (Nuremberg, 1947) vol 1 at 54; and the Secretary-General of the United Nations Report of the Secretary-General Pursuant to Paragraph 2 of Security Council Resolution 808 (1993) UN Doc S/25704 (3 May 1993); both cited in Legality of the Threat or Use of Nuclear Weapons, above n 35, at 258.

122 Price, above n 111, at 15.

123 Hague Declaration concerning Asphyxiating Gases (adopted 29 July 1899, entered into force 4 September 1900).

124 Price, above n 111, at 167. See also GA Res 47/39, above n 16, preamble: "Recalling the long-standing determination of the international community to achieve the effective prohibition of the development, 
In relation to nuclear weapons, the International Court of Justice concluded in 1996 that customary international law did not contain a comprehensive and universal prohibition on their use. ${ }^{125}$ The Court considered whether existing principles and rules of humanitarian law apply to nuclear weapons and whether they might lead to a prohibition on the use of nuclear weapons in every circumstance. ${ }^{126} \mathrm{It}$ found that such principles and rules of humanitarian law do apply to nuclear weapons and that their use - given the "unique characteristics" of nuclear weapons - "seems scarcely reconcilable" with those rules. ${ }^{127}$ However the Court determined that it was not possible to find that the use of nuclear weapons would necessarily be "at variance" with the laws applicable in armed conflict in every circumstance. ${ }^{128}$

The Court identified an "increasing concern in the international community" in relation to nuclear weapons. ${ }^{129}$ However it found that "members of the international community were profoundly divided" on whether the non-use of nuclear weapons since 1945 constituted an expression of an opinio juris that their use was unlawful. ${ }^{130}$ In particular a number of States maintained before the Court that they had always reserved the right to use nuclear weapons in self-defence and maintained their support for the practice of deterrence. ${ }^{131}$ The Court also noted States that possess nuclear weapons have registered their objection to the nascent opinio juris that every possession or use of nuclear weapons is unlawful by refusing to support General Assembly resolutions which condemn the use of nuclear weapons. ${ }^{132}$ The Court ultimately found that there was a "nascent" opinio juris to the effect that the use of nuclear weapons in all circumstances was unlawful but that it was in tension with "strong adherence to the practice of deterrence". ${ }^{133}$

production, stockpiling and use of chemical weapons, and their destruction, as well as the continuing support for measures to uphold the authority of the [Geneva Protocol]."

125 Price, above n 111, at 266. The Court also found that in 1996 conventional international law lacked this comprehensive prohibition.

126 At 261.

127 At 262.

128 At 263.

129 At 253. This concern was manifested for example through General Assembly resolutions.

130 At 254

131 At 266

132 Starting with Declaration on the prohibition of the use of nuclear and thermo-nuclear weapons GA Res 1653 (1961). See the discussion of these resolutions in Legality of the Threat or Use of Nuclear Weapons, above $\mathrm{n}$ 35 , at 254 .

133 Legality of the Threat or Use of Nuclear Weapons, above n 35, at 255. 
In response to the TPNW, the United Kingdom, the United States, Pakistan and India - all States that possess nuclear weapons - have issued statements to the effect that they consider that the Treaty does not contribute to the development of customary international law. ${ }^{134}$

\section{WHAT LESSONS ARE TO BE LEARNT AS TO THE PROBLEM OF CHANGE?}

To summarise, there are striking differences between the regulatory history of the two kinds of weapon in our time. The "difference of views with regard to the legal status" of nuclear weapons identified by the International Court in 1996 has persisted. ${ }^{135}$ The prohibition in the TPNW on the use and possession of nuclear weapons in all circumstances has not been supported by any of the States that possess nuclear weapons and the formation of a customary prohibition on the possession and use of nuclear weapons in all circumstances is hindered by the presence of persistent objectors. ${ }^{136}$ By contrast a comprehensive prohibition on the use and possession of chemical weapons embodied in the CWC emerged despite initial resistance from some States. ${ }^{137}$ Contrasting attempts to outlaw chemical weapons with attempts to outlaw nuclear weapons provides some lessons for future efforts for the suppression of the possession and use of nuclear weapons. What lessons are to be learnt from this?

\section{A Multilateral Verification and Implementing Treaty Body}

The first lesson is organisational. A trusted multilateral verification regime is key to achieving comprehensive nuclear disarmament. ${ }^{138}$ A major breakthrough that helped lead to the conclusion of the CWC was the Soviet Union's acceptance in August 1987 of an intrusive verification regime as part of a treaty prohibiting the use of chemical weapons. ${ }^{139}$ The United States' acceptance two years

134 See France, United Kingdom and United States Joint Press Statement, above n 73; Ministry of Foreign Affairs of Pakistan "Press Statement on the Treaty on the Prohibition of Nuclear Weapons" (7 August 2017); and Ministry of External Affairs of India "Response by the Official Spokesperson to a media query regarding India's view on the Treaty to ban nuclear weapons" (18 July 2017).

135 Legality of the Threat or Use of Nuclear Weapons, above n 35, at 263.

136 The International Law Commission in its Third report, above n 7, at 66, confirmed that a state "may deny that an emerging rule has become a rule of customary international law, or object to the applicability of the rule to itself, or do both". In this case it is the denial of the emergence of a new rule that is relevant.

137 For example at the 1925 League of Nations Conference for the Supervision of the International Trade in Arms and Ammunition and in Implements of War at Geneva, the Brazilian representative indicated that in his view a prohibition on the trade of "gas weapons" would be unfair to States that did not produce them, especially because chemical weapons were an effective means of defence for weak countries: J Goldblat The Problem of chemical and biological weapons (Almqvist \& Wiksell, Stockholm, 1971) vol 4 at 59 as cited in Jefferson, above $\mathrm{n} 9$, at 658 .

138 Report of the Canberra Commission on the Elimination of Nuclear Weapons, above n 108, at 13.

139 OPCW, above $n 67$. 
later that a verification regime for chemical weapons could be created that would satisfy their concerns about the proliferation of chemical weapons also bolstered efforts to finalise the CWC. ${ }^{140}$

The potential for one state to develop nuclear weapons (clandestinely or otherwise) at the same time as other states agree multilaterally to disarm is a concern of States that possess nuclear weapons. It is used as an explanation for their retention of nuclear weapons. ${ }^{141}$ In particular, North Korea is seen as a threat. ${ }^{142}$ North Korea did not attend the vote at which the TPNW was adopted: in this it was not alone. In 2003 North Korea officially maintained that it had "no intention to produce nuclear weapons" and that its "nuclear activities" were confined "only to peaceful purposes"; 143 however the present position seems to be very different. It is suspected of having recently tested nuclear weapons and of accelerating its nuclear weapons programme. ${ }^{144}$ North Korea is the only state to have announced the conduct of nuclear weapon tests since 1998, when India and Pakistan conducted two tests each. ${ }^{145}$ Finally, North Korea purported unilaterally to withdraw from the NPT in 2003. ${ }^{146}$ The ideal verification regime would operate independently from state consent. One hundred and sixtyeight States are members of the IAEA, ${ }^{147}$ which is responsible for international activities concerned with the peaceful use of nuclear energy. ${ }^{148}$ One of the IAEA's functions is to establish and administer safeguards to ensure that special fissionable and other materials and equipment are not used to further

140 George Bush, President of the United States "Address to the 44th Session of the UN General Assembly" (New York, 25 September 1989): "the knowledge we've gained from our recent arms control experience and our accelerating research in this area makes me believe that we can achieve the level of verification that gives us confidence to go forward with the ban". See also Robinson, above n 65, at 27.

141 See France, United Kingdom and United States Joint Press Statement, above n 73: "This treaty offers no solution to the grave threat posed by North Korea's nuclear program, nor does it address other security challenges that make nuclear deterrence necessary."

142 France, United Kingdom and United States Joint Press Statement, above n 73.

143 "Official Statement of the Government of the DPR of Korea: Withdraw[al] of the Nuclear Non Proliferation Treaty" (10 January 2003).

144 Preparatory Commission for the Comprehensive Nuclear-test-ban Treaty Organization "CTBTO Executive Secretary Lassina Zerbo on the Unusual Seismic Event Detected in the Democratic People's Republic of Korea" (press release, 3 September 2017).

145 Preparatory Commission for the Comprehensive Nuclear-test-ban Treaty Organization "World Overview" $<$ www.ctbto.org $>$.

146 According to the United Nations Office of Disarmament Affairs online treaty database: "On 10 January 2003 , the Democratic People's Republic of Korea (DPRK) announced its withdrawal from the Treaty in a public statement. States parties to the Treaty continue to express divergent views regarding the status of the DPRK under the NPT."

147 Included in that figure are the following States whose membership has been approved by the IAEA General Conference but will only take effect once the necessary legal instruments have been deposited with the IAEA: Cabo Verde, Comoros, Grenada, Saint Lucia, Saint Vincent and the Grenadines, The Gambia and Tonga.

148 IAEA Medium Term Strategy 2018-2023 at 1. 
any military purpose and to apply safeguards to any of state's activities in the field of atomic energy. ${ }^{149}$ However a state must consent to IAEA membership and must conclude Safeguard Agreements with the organisation. ${ }^{150}$ The example of North Korea demonstrates the limitations of IAEA verification. In 1994 North Korea withdrew its membership of the IAEA ${ }^{151}$ and took the view that this meant that it was no longer obliged to allow IAEA inspectors to carry out their work under its Safeguards Agreement. ${ }^{152}$ It expelled inspectors on 27 December 2002, ${ }^{153}$ leaving nuclear material in North Korea without any monitoring by the IAEA. ${ }^{154}$ While Kim Jong-un announced his commitment "to work toward complete denuclearization of the Korean Peninsula" in June 2018 in the context of bilateral negotiation with the United States, ${ }^{155}$ the IAEA maintained in September 2018 that "[t]he further development of the DPRK's nuclear programme ... and related statements by the DPRK, are a cause for grave concern." 156

The foundations for a robust verification regime already exist. The Preparatory Commission for the Comprehensive Nuclear-Test-Ban Treaty Organization has built up a verification regime in preparation for the entry into force of the Comprehensive Nuclear-Test-Ban Treaty. The Organization's monitoring system detected the most recent purported nuclear test by North Korea on 3 September 2017 and had previously detected tests in 2006. ${ }^{157}$ A proper trusted verification regime reduces the likelihood that so-called "rogue" states can develop a nuclear weapons capability in breach

149 Statute of the IAEA 276 UNTS 3 (opened for signature 23 October 1956, entered into force 29 July 1957), $\operatorname{art} \operatorname{III}(\mathrm{A})(5)$.

150 "Further, the verification required under IAEA safeguards agreements depends primarily on the facilities which each State party to the NPT identifies on its own territory": United Nations Disarmament: Responding to New Realities in Disarmament - Excerpts from the panel discussions at the Disarmament Week Symposium held at the United Nations in New York, 26-27 October 1993 (United Nations, New York, 1994) at 9.

151 It had joined the IAEA in 1974. IAEA "Fact Sheet on DPRK Nuclear Safeguards" <www.iaea.org > . In the IAEA's view the Safeguards Agreement remained binding and in force despite the withdrawal.

152 Agreement of 30 January 1992 between the Government of the Democratic People's Republic of Korea and the International Atomic Energy Agency for the Application of Safeguards in Connection with the Treaty on the Non-Proliferation of Nuclear Weapons (signed 30 January 1992, entered into force 10 April 1992).

153 IAEA, above n 148.

154 IAEA "IAEA Board Meets 6 January to Consider Next Steps on DPRK Issue" (3 January 2003) $<$ www.iaea.org $>$.

155 "Joint Statement of President Donald J Trump of the United States of America and Chairman Kim Jong Un of the Democratic People's Republic of Korea" (12 June 2018).

156 IAEA Director General "Introductory Statement to the Board of Governors" (September 2018).

157 Preparatory Commission for the Comprehensive Nuclear-test-ban Treaty Organization "DPRK Sept 2017 Unusual Seismic Event" <www.ctbto.org>; and Preparatory Commission for the Comprehensive Nucleartest-ban Treaty Organization "The CTBT Verification Regime put to the test - the event in the DPRK on 9 October 2006" <www.ctbto.org>. 
of official commitments to other states and without the knowledge of others. A related organisational consideration is that a multilateral treaty body is required to implement and verify the existing obligations on nuclear-weapon States, as defined in the NPT, to achieve nuclear disarmament in all its aspects. ${ }^{158}$ The CWC created the OPCW, which ensures the implementation of the convention and verification of States Parties' obligations. ${ }^{159}$ The OPCW is constituted by an Executive Council, the Conference of State Parties and the Secretariat whose respective roles are laid down in the CWC. ${ }^{160}$ Among other things the Conference of State Parties adopts the programme of the OPCW and makes "decisions on any questions, matters or issues" related to the CWC. ${ }^{161}$ A party to the CWC cannot be deprived of OPCW membership. ${ }^{162}$

There is no parallel organisation in the field of nuclear disarmament. The NPT did not create a treaty body to oversee the implementation of its "mutually reinforcing objectives" of horizontal nonproliferation and nuclear disarmament by nuclear-weapon States. ${ }^{163}$ While every five years, parties to the NPT meet to review its implementation, there is no treaty body with a specific mandate to facilitate good faith negotiations towards nuclear disarmament or to develop effective measures towards disarmament with a view to implementing Article VI of the NPT. The NPT's nonproliferation objective has been facilitated through IAEA assistance, including Safeguard Agreements. The TPNW will also rely on IAEA Safeguard Agreements for compliance verification once it enters into force. ${ }^{164}$ The IAEA was originally also mandated to apply safeguards to "any bilateral or multilateral arrangement" 165 and conduct its activities in conformity with policies of the United Nations "furthering the establishment of safeguarded worldwide". ${ }^{166}$ However IAEA safeguards have not previously been applied to nuclear disarmament activities because of resistance by some States. 167

158 Working Paper submitted by Ireland on behalf of the New Agenda Coalition, above n 107, at [26(vii)]. The International Court of Justice identified this existing obligation pursuant to art VI of the NPT: Legality of the Threat or Use of Nuclear Weapons, above n 35, at 264.

159 CWC, above n 8, art VIII.

160 Article VIII.

161 Article VIII(B)(19).

$162 \operatorname{Art} \operatorname{VIII}(\mathrm{A})(2)$.

163 Working Paper submitted by Ireland on behalf of the New Agenda Coalition, above n 107, at [2]. See NPT, above n 39, arts I-III and VI.

164 TPNW, above n 47, art 3 .

165 Statute of the IAEA, above n 149, art III(A)(5).

166 Article III(B)(1).

167 Working Paper submitted by Ireland on behalf of the New Agenda Coalition, above n 107, at [12]. 


\section{B A Staged Approach to Nuclear Disarmament}

Second, there are lessons about appropriate mechanisms for change. A staged approach to nuclear disarmament through bilateral agreements (between two States that possess nuclear weapons, and between a State that possesses nuclear weapons and a non-nuclear-weapon State) and security assurances should be adopted. ${ }^{168}$ The CWC provides for the elimination from use, and the destruction, of an entire category of weapons. ${ }^{169}$ However the recent attempt to outlaw nuclear weapons through the TPNW, providing for the comprehensive elimination of nuclear weapons, has not received the support of States that possess nuclear weapons.

The argument for a staged approach is supported by earlier attempts to outlaw the use of nuclear weapons, which have demonstrated that staged nuclear disarmament is more acceptable to States that possess nuclear weapons. These States have shown their willingness to agree not to use nuclear weapons in particular geographical areas, ${ }^{170}$ within nuclear-free-zones ${ }^{171}$ or against certain other states or groups of states. ${ }^{172}$ They have also committed not to use nuclear weapons in certain situations. ${ }^{173}$ Amongst the States that possess nuclear weapons, there are calls for the broadening of circumstances in which the use of nuclear weapons is prohibited by treaty: China seeks the elaboration

168 This approach was recommended in the Report of the Canberra Commission on the Elimination of Nuclear Weapons, above n 108.

169 According to the United Nations Office of Disarmament Affairs, the CWC is the first disarmament agreement negotiated within a multilateral framework that provides for the elimination of an entire category of weapons of mass destruction under universally applied international control.

170 For example, nuclear explosions are prohibited in the Antarctic pursuant to art V of The Antarctic Treaty, above n 38. All nuclear-weapon States are parties to the Treaty except for Pakistan and Israel.

171 See for example Treaty of Pelindaba, above n 38, protocol I art 1. The United States supports the establishment of nuclear-free-zones: Christopher Buck, Deputy Chief of Mission, Delegation to the Conference on Disarmament Permanent Mission "Statement to the Third Meeting of the Preparatory Committee for the 2015 Nuclear Non-Proliferation Treaty Review Conference" (United Nations, New York, 2 May 2014): "The United States also supports well-crafted nuclear-weapon-free zones (NWFZs) that are vigorously enforced and developed in accordance with the guidelines adopted by the United Nations Disarmament Commission."

172 For example China's negative assurance: "Statement by HE Ambassador Hu Xiaodi on Security Assurances for Non-Nuclear-Weapon States at the Main Committee I of the 2005 NPT Review Conference" (New York, 24 May 2005) that "China has all along committed not to be the first to use nuclear weapons at no time or under no circumstances, nor use or threaten to use nuclear weapons against non-nuclear-weapon states and nuclear-weapon-free zones, thus providing unconditional negative security assurances to non-nuclear-weapon states."

173 "Statement by HE Ambassador Hu Xiaodi", above n 172. 
of a treaty on the mutual no-first-use of nuclear weapons ${ }^{174}$ and Russia has expressed its support for the bringing into force of the Comprehensive Nuclear-Test-Ban Treaty. ${ }^{175}$

Incremental progress towards nuclear disarmament has occurred through bilateral agreements between States that possess nuclear weapons (sometimes with fixed timelines for disarmament) rather than multilateral treaties. A telling example is that in the decade to September 2000, during which time the United States and the Soviet Union (then Russia) engaged in successive agreements in relation to strategic weapons, the number of United States deployed strategic nuclear weapons reduced by approximately half. ${ }^{176}$ The preference shown by States that possess nuclear weapons for bilateral agreements as a means of committing to specific disarmament targets is linked to security concerns. This is evidenced by the fact that these States appear more likely to commit to tangible disarmament goals when they are matched by other States that possess nuclear weapons. ${ }^{177}$ Staged disarmament recognises the security concerns of nuclear-weapon States and ensures they are confident with and committed to the next stage in the process of disarmament. ${ }^{178}$

Nuclear disarmament is more likely to be successful if it is not conditional on horizontal nonproliferation. The two objectives - disarmament and non-proliferation - are linked in the NPT. The United States justifies its possession of nuclear weapons for deterrent purposes by its position that its own possession of nuclear weapons, coupled with assurances provided to its allies, enables other states to "eschew possession of nuclear weapons", thereby encouraging non-proliferation. ${ }^{179}$ Concern by States that possess nuclear weapons that non-nuclear-weapon States are developing nuclear weapons has limited their compliance with their NPT commitments. ${ }^{180}$ Once horizontal proliferation is

174 "Statement by HE Mr Cheng Jingye Head of the Chinese Delegation to the First Session of the Preparatory Committee for the 2015 Review Conference of the Parties to the Treaty on the Non-Proliferation of Nuclear Weapons" (Vienna, 30 April 2012) at 4: "The nuclear-weapon states should unequivocally undertake not to be the first to use nuclear weapons and negotiate and conclude the Treaty on Mutual No-First-Use of Nuclear Weapons."

175 Sergey Lavrov, Russian Foreign Minister "Statement at the Conference on Disarmament" (Geneva, 28 February 2018).

176 Nina Tannenwald The Nuclear Taboo (Cambridge University Press, Cambridge, 2007) at 330.

177 For example, the series of United States-Russian bilateral disarmament treaties since 1994: START I, above n 46; START II, above n 46; SORT, above n 46; and New START, above n 46. See also the India-Pakistan Lahore Declaration (21 February 1999). However, there are examples of unilateral nuclear disarmament, notably South Africa: Disarmament: Responding to New Realities in Disarmament, above n 50, at i.

178 Report of the Canberra Commission on the Elimination of Nuclear Weapons, above n 108, at 51.

179 United States Department of Defense, above n 83, at VIII.

180 In particular their commitments pursuant to art VI. See North Atlantic Treaty Organization "The Nuclear Weapons Ban Treaty: reasons for skepticism" (19 May 2017) <www.nato.int> [NATO], which notes the "grave threat posed by North Korea's nuclear programme", concluding that "the treaty fails to take into account these urgent security challenges". 
contained, the logic of each state maintaining a nuclear arsenal (for deterrence or retaliation) disappears. ${ }^{181}$ Conversely as long as nuclear disarmament and non-proliferation remain linked the retention of nuclear weapons by States that already possess them might lead to attempts by nonnuclear-weapon States to acquire nuclear weapons. ${ }^{182}$ This is because the possession of nuclear weapons by any state stimulates the desire by other states to acquire them. ${ }^{183}$

According to some States that possess nuclear weapons, horizontal non-proliferation of nuclear weapons is key to achieving general nuclear disarmament. ${ }^{184}$ One hundred and eighty-six nonnuclear-weapon States have already ratified the NPT, which includes an undertaking by them not to manufacture or acquire nuclear weapons. ${ }^{185}$ Despite this, States that possess nuclear weapons have sought to justify their rejection of the TPNW by pointing to a dangerous security situation, including the possession by other states of nuclear weapons. ${ }^{186}$ States that possess nuclear weapons have also in many instances made negative security assurances conditional on nuclear non-proliferation in the state receiving the security assurance. ${ }^{187}$ Wide ratification of and compliance with the TPNW could disaggregate nuclear non-proliferation and nuclear disarmament by removing concerns over horizontal non-proliferation as an obstacle to disarmament.

On a normative level, the enactment of an international legal prohibition on the possession and use of nuclear weapons in all circumstances contributes to placing these actions outside the ambit of "responsible statehood". ${ }^{188}$ The corollary is that the TPNW could create a new social standard in

181 Report of the Canberra Commission on the Elimination of Nuclear Weapons, above n 108, at 24: "The only military utility that remains for nuclear weapons is in deterring their use by others. That utility implies the continued existence of nuclear weapons. It would disappear if nuclear weapons were eliminated."

182 Working Paper submitted by Ireland on behalf of the New Agenda Coalition, above n 107, at [34].

183 Report of the Canberra Commission on the Elimination of Nuclear Weapons, above n 108, at 18.

184 See France, United Kingdom and United States Joint Press Statement, above n 73: "We reiterate in this regard our continued commitment to the Treaty on the Non-Proliferation of Nuclear Weapons (NPT) and reaffirm our determination to safeguard and further promote its authority, universality and effectiveness."

185 NPT, above n 39, art II. North Korea acceded to the NPT on 12 December 1985 but announced its withdrawal from the NPT on 10 January 2003.

186 For example, Nikki Haley, United States United Nations envoy, stating that: "There is nothing I want more for my family than a world with no nuclear weapons. But we have to be realistic." See also NATO, above $n$ 180 .

187 For example France's declaration to Protocol I of the Treaty of Pelindaba, above n 38: France's "assurances do not apply to States which are not parties to the Treaty on the Non-Proliferation of Nuclear Weapons". In relation to the United States negative security assurance, see Steven Pifer and others US Nuclear and Extended Deterrence: Considerations and Challenges (The Brookings Institution, Arms Control Series Paper 3, May 2010) at 16.

188 Adam Bower Norms Without the Great Powers (Oxford University Press, Oxford, 2017) at 32. 
terms of a total prohibition on the use and possession of nuclear weapons, by which states will conform in order to achieve the status of a "civilised" state. ${ }^{189}$

Bilateral or limited multi-party agreements can also be an effective way of curtailing horizontal nuclear proliferation. ${ }^{190}$ Such agreements also foster a security environment which might be perceived as favourable to nuclear disarmament by States that possess nuclear-weapons. The Joint Comprehensive Plan of Action (JCPOA) can be seen as an example of both the role of multi-party agreements in the strengthening of nuclear non-proliferation, but also their limitations in terms of progressing nuclear disarmament. ${ }^{191}$ In relation to the latter point, the United States withdrew from the plan in May 2018, citing security concerns in relation to Iran's nuclear ambitions. ${ }^{192}$ As to the former, Iran, a state which the Security Council had previously found in breach of its IAEA obligations ${ }^{193}$ has committed to specific non-proliferation obligations as contained in the JCPOA. Iran's commitment to the terms of the JCPOA, and to its IAEA nuclear-related obligations, continue despite the United States withdrawal. ${ }^{194}$

States that possess nuclear weapons argue that nuclear disarmament will come from a commitment to the NPT rather than the new TPNW prohibition. ${ }^{195}$ In this regard, when the United States withdrew from the JCPOA it sought to justify its action, in part, by Iran's past violation of the NPT as evidence that the JCPOA's verification mechanism was inadequate. ${ }^{196}$

The problem remains that, while the NPT contains a clear prohibition on the acquisition of nuclear weapons by new States, ${ }^{197}$ it contains no specific temporal or logistical obligations for disarmament.

189 At 32, citing Tannenwald, above n 176, at 433 and 347.

190 See for example the Iran-United States and European Union deal, as to which see International Crisis Group Implementing the Iran Nuclear Deal: A Status Report (Middle East Report No 173, 16 January 2017); and "The Iran nuclear accord: Making the world a bit safer" The Economist (online ed, United States, 18 July 2015).

191 Iran, China, France, Russia, the United States, the United Kingdom and the European Union Joint Comprehensive Plan of Action (14 July 2015).

192 United States Presidential Memorandum "Ceasing US Participation in the JCPOA and Taking Additional Action to Counter Iran's Malign Influence and Deny Iran All Paths to a Nuclear Weapon" (8 May 2018).

193 SC Res 1929 (2010) at [1].

194 "Statement from the Joint Commission of the Joint Comprehensive Plan of Action" (6 July 2018).

195 See French Ministry for Europe and Foreign Affairs "Adoption of a treaty banning nuclear weapons" (press release, 7 July 2017): "Nuclear disarmament is not achieved by decree, it must be built. France, for its part, remains determined to implement the next concrete stages in nuclear disarmament, in accordance with its commitments under the Treaty on the Non-Proliferation of Nuclear Weapons."

196 United States Presidential Memorandum, above n 192.

197 NPT, above n 39, art II. 
This enables nuclear-weapon States, as defined in the NPT, to slow their nuclear disarmament in response to their perceived security environment. Most recently, the United States reiterated its commitment to the NPT in its 2018 Nuclear Posture Review but added that "the current environment makes further progress toward nuclear arms reductions in the near term extremely challenging". ${ }^{198}$

\section{Lessons in Realpolitik}

Finally, there are lessons in realpolitik. Another breakthrough that led to the conclusion of the CWC was the United States' willingness to renounce in 1992 the option of retaliation in kind with chemical weapons. The adoption of the TPNW has identified the position of each state in relation to their willingness to support the comprehensive prohibition on the use and possession of nuclear weapons. Seven of the nine States that possess nuclear weapons officially support comprehensive nuclear disarmament ${ }^{199}$ and many of their strategic military allies do so as well. ${ }^{200}$ However, States that possess nuclear weapons point to the existence of a security situation that they say does not allow for complete nuclear disarmament. ${ }^{201}$ They maintain long-held deterrence policies and reserve the right to lawfully use nuclear weapons in some circumstances. In particular, States that possess nuclear weapons reserve the right to use nuclear weapons in belligerent reprisals, which is irreconcilable with comprehensive nuclear disarmament. ${ }^{202}$ The progression of nuclear disarmament through international agreements needs to take account of these factors.

To conclude, the International Court recognised in 1996 that the "realistic search" for nuclear disarmament "necessitates the co-operation of all States". ${ }^{203}$ This includes the agreement of States

198 United States Department of Defense, above n 83, at III.

199 See statements by India: "Statement by Ambassador Amandeep Singh Gill, Permanent Representative of India to the Conference on Disarmament" (28 March 2017); Pakistan, above n 134; China, above n 87, at [4] and [16]-[17]; and joint statement by France, the United Kingdom and the United States, above $n$ 73, in relation to the TPNW. France, United Kingdom and United States Joint Press Statement, above n 73, recognises the "shared goal of nuclear disarmament and general and complete disarmament". See also statement by the Russian Federation, above $\mathrm{n} 74$, in relation to the 2015 conference of the NPT.

200 See for example Julie Bishop, Australian Foreign Minister "Working towards a nuclear weapons-free world" (press release, 20 September 2017): "I will continue Australia's tireless efforts to achieve a world free of nuclear weapons." See also "German Statement at the high-level plenary meeting of the Assembly to commemorate and promote the International Day for the Total Elimination of Nuclear Weapons" (26 September 2017): "A world without nuclear weapons is a shared responsibility of each and every one of us. The German government entirely shares this goal."

201 France, United Kingdom and United States Joint Press Statement, above n 73: the TPNW "clearly disregards the realities of the international security environment".

202 Where nuclear-weapon States have provided negative security assurances to non-nuclear-weapon States in the context of the NPT or nuclear-weapons-free zone agreements, they have generally preserved their right to the use of nuclear weapons in response to the use of nuclear weapons by another State.

203 Legality of the Threat or Use of Nuclear Weapons, above n 35, at 264. 
that possess nuclear weapons and their strategic allies. The cooperation of these States is so far absent in relation to the TPNW. As the Canberra Commission wrote in 1996: ${ }^{204}$

The key responsibility lies with the nuclear weapon states ... and in particular with the United States and Russia. The invigoration of the elimination progress [of nuclear weapons] will depend on decisions which they alone can make.

204 Report of the Canberra Commission on the Elimination of Nuclear Weapons, above n 108, at 30. 